\title{
Descriptive Study of Pushover Analysis in RCC Structures of Rigid Joint
}

\author{
Yousuf Dinar ${ }^{1}$, Md. Imam Hossain ${ }^{2}$, Rajib Kumar Biswas ${ }^{2}$, Md. Masud Rana ${ }^{3}$ \\ ${ }^{1,2,3}$ Graduate Student, Department of Civil Engineering, University of Asia Pacific, Bangladesh \\ ${ }^{2}$ Graduate Student, Department of Civil Engineering, Ahsanullah University of Science and Technology,
} Bangladesh

\begin{abstract}
Structures in mega cities, are under serious threat because of faulty and unskilled design and construction of structures. Sometimes structure designers are more concerned in constructing different load resistant members without knowing its necessity and its performance in the structure. Different configuration of construction may also lead to significant variation in capacity of the same structure. Nonlinear static pushover analysis provides a better view on the performance of the structures during seismic events. This comprehensive research evaluates as well as compares the performances of bare, different infill percentage level, different configuration of soft storey and Shear wall consisting building structures with each other and later depending upon the findings, suggests from which level of performance shear wall should be preferred over the infill structure and will eventually help engineers to decide where generally the soft storey could be constructed in the structures. Above all a better of effects of pushover analysis could be summarized from the findings. Masonry walls are represented by equivalent strut according to pushover concerned codes. For different loading conditions, the performances of structures are evaluated with the help of performance point, base shear, top displacement, storey drift and stages of number of hinges form.
\end{abstract}

Keywords: Performance, pushover analysis, infill percentage, shear wall, soft storey, equivalent strut, storey drift

\section{INTRODUCTION}

In last few years the widespread damage to reinforced concrete building during earthquake generated demand for seismic evaluation and retrofitting of existing building in Dhaka. In addition, most of our buildings built in past two decades are seismically deficient because of lack of awareness regarding structural behavior during earthquake and reluctance to follow the code guidelines. Among different frame system, Rigid Joint is most constructed frame system in South Asia which is also known as column beam joint frame system. It has a limitation to construct the structure till 30 floors only. This frame structure is economical to construction so it becomes popular among general people but has a serious damage in joint under the seismic events. This structure system hold the fame system by column beam joint and during seismic events those point prone to cracked due to faulty and inappropriate design and construction. Accuracy of design may fall due not considering infill percentage and soft storey and its varying configuration effects which significantly change the performance of the frame system. Besides that construction of shear-wall may leads to over design so a solution is required to get optimum level during design phase.

Infill could be mentioned by masonry wall which increase the stiffness of the floor and the building overall. Infill may create Soft story effects and becomes a cause of destruction. Soft-story term is used to indicate having a storey much less rigid than the stories above or below, is particularly susceptible to earthquake damage because of large, unreinforced openings on their specific floor and in their typically RC frame structure. These openings often used as parking spaces, large windows, expansive lobbies and commercial place in residential and commercial buildings Figure 1. Without proper design, such structures are much less able to withstand the lateral forces that push a structure side to side such as those earthquakes generate.

Structural engineering is expending with advancement of science, research and technology by including different new analyses, terms and parameters. Several nonlinear analyses are now available which were not performed a few years ago due to lack of knowledge, technology and simplicity. One of the mentionable nonlinear but static analysis is Pushover analysis, which deals with static load cases only but consider nonlinear characteristics of materials. This analysis has been developed over the past twenty years and has become the preferred analysis procedure for design and seismic performance evaluation purposes as the procedure are relatively simple and consider post elastic behavior. This nonlinear static analysis where the lateral loads is increased keeping vertical loads constant, to maintaining a predefined distribution pattern along the height of the building, until a collapse mechanism develops and this performance based approach requires a lateral loads versus deformation analysis. The pushover analysis is a method to observe the successive damage states of a building. However, the procedure involves certain approximations and simplifications that some 
amount of variation is always expected to exist in seismic demand prediction of pushover analysis. Pushover analysis of finite element was performed by ETABS 9.7.2 where the deficiencies of this analysis are the following features.

1. The analysis considers the inelastic deformation and ductility of the members.

2. The sequence of yielding of sections in members and redistribution of loads in the building are observed.

The structural engineering profession has been using the nonlinear static procedure (NSP) or pushover analysis described in FEMA-356 and ATC-40, when pushover analysis is used carefully it provides useful information that cannot be obtained by linear static or dynamic analysis procedure.

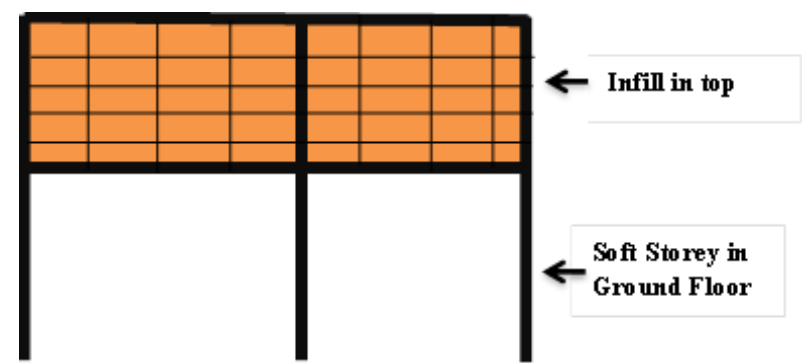

Figure 1: Formation of Soft storey in Ground Floor

This research paper is an improved and extended version of research study of previous published paper in European Academic Research of the same corresponding author.

The purpose of this extended research is to investigate as well as compares the performances of bare, different infill percentage level, different configuration of soft storey and Shear wall consisting building structures with each other and later depending upon the findings, suggests from which level of performance shear wall should be preferred over the infill structure and will eventually help engineers to decide where generally the soft storey could be constructed in the structures. Force unit is $\mathrm{KN}$ while displacements are measured in $\mathrm{mm}$.

\section{METHODOLOGY}

As stated before, pushover analysis is a static, nonlinear procedure in which the magnitude of the lateral force is incrementally increased, maintaining the predefined distribution pattern along the height of the building. With the increase in the magnitude of the loads, weak links and failure modes of the building are found. Pushover analysis can determine the behavior of a building, including the ultimate load and the maximum inelastic deflection. Local Nonlinear effects are modeled and the structure is pushed until a collapse mechanism gets developed. At each step, the base shear and the roof displacement can be plotted to generate the pushover curve. It gives an idea of the maximum base shear that the structure was capable of resisting at the time of the earthquake. For regular buildings, it can also give a rough idea about the global stiffness of the building. In soft storey the displacement will be maximum in nature as they have no sufficient strength to take loads from above storey but as the soft storey is shifted bottom to top of the structure the results may be found reverse where strength will eventually increases.

7 storied frame structures are simulated and checked with the help of finite element software ETABS 9.7.2 to perform the pushover analysis to meet the objectives of this study. Each and every storey is kept soft storey for different case to get the changing trend. Earth quake effect is assigned by the software which is done by UBC 94. Wind load is calculated according to Bangladesh National Building Code (BNBC) by developing an excel sheet to get point loads. Dead load and live load are taken according to standard practice among the professional designers and engineers. Standard load combinations are taken according to BNBC. To perform the pushover ATC -40 is reviewed whole through the study. All three types of hinges required for performing pushover analysis of RC structure are chosen from the experimental data and experience. Allowable hinge deformation at different performance level for beams and columns is computed and established. All three types of hinges are assigned to each element according to required type. Structure are then subjected to push over analysis which include progressive damage of elements with plastic deformation of the hinge assigned on the element of the structure as the structure is laterally pushed through. After simulation the structural response will be used to give the light on changing characteristics. 


\section{Details OF PUShover ANALYSIS}

Pushover analysis provides a wide range of application options in the seismic evaluation and retrofit of structures. Mainly two guidelines are available for this analysis- FEMA and ATC 40. This paper mainly follows the procedures of ATC 40 in evaluating the seismic performance of residential building consisting shear wall in Dhaka. Here the pushover analysis of the structure represents a static nonlinear analysis under constant vertical loads and gradually increasing lateral loads. Equivalent Static lateral loads approximately represent seismic generated forces. Analysis is carried out till to failure of the structures. This analysis identifies weakness in the structure so that appropriate retrofitting could be provided in governing element. Basically, demand and capacity are the two component of the performance based analysis and design where demand is a representation of the seismic ground motion and capacity is a representation of the structure ability to resist seismic demand. The performance is dependent in a manner that the capacity is able to handle the seismic demand. Once the capacity curve and demand displacement are defined, a performance check can be done. In our study, nonlinear static pushover analysis was used to evaluate the seismic performance of the structures. The numerical analysis was done by ETABS 9.7.2 and guidelines of ATC-40 and FEMA 356 were followed. Overall evaluation was done using base shear, deflection, storey drift, storey drift ratio and stages of number of hinges form. Plastic hypotheses was used to mark the nonlinear behavior according to which plastic deformations are lumped on plastic hinges and rest of the system shows linear elastic behavior( Li 1996). The discrete structural performance levels are- Immediate Occupancy (S-1), Life Safety (S-3), Collapse Prevention (S-5) and Not Considered (S-6)

Whereas intermediate structural performance ranges are the Damage Control Range (S-2) and the Limited Safety Range(S-4) Figure 1.This definition of performance ranges are served by FEMA 356, 2000. The model frame used in the static nonlinear pushover analysis is based on the procedures of the material, defining force - deformation criteria for the hinges used in the pushover analysis. Figure 2 describes the typical forcedeformation relation proposed by those documents.

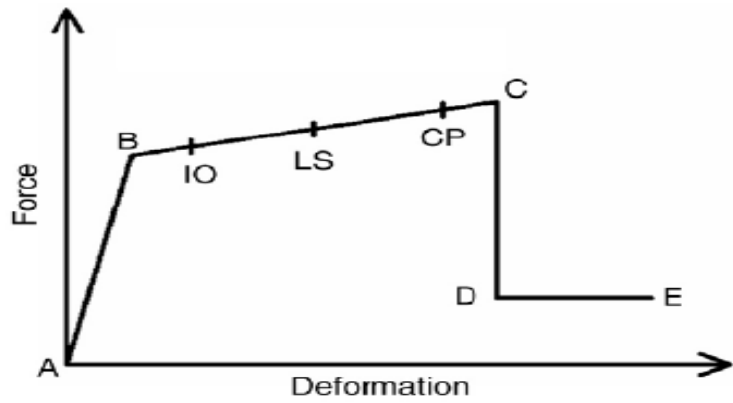

Figure 2: Force-Deformation for pushover analysis

Five points labeled A, B, C, D and E are used to define the force deflection behavior of the hinge and these points labeled A to B - Elastic state, B to IO- below immediate occupancy, IO to LS - between immediate occupancy and life safety, LS to CP- between life safety to collapse prevention, CP to C - between collapse prevention and ultimate capacity, C to D- between $\mathrm{C}$ and residual strength, D to E- between D and collapse >E collapse. In ETABS 9.7.2 those points could be identified by color bands to understand how plastic hinges form in each stage Figure 3 where IO, LS and CP mean immediate occupancy, life safety and collapse prevention respectively.

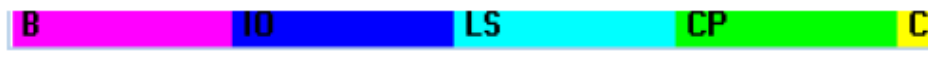

Figure 3: Force-Deformation for pushover analysis

\section{Details of Structural Models}

For Numerical modeling, a sample RC three dimensional building is selected. The structure is seven storeys high, with a storey height of 3 meters. The bay lengths are $5 \mathrm{~m}-5 \mathrm{~m}$ in both directions Fig. 4 . In order to concentrate on the effects caused by the distribution of infill the prototype bare frame structure is regular throughout its bay length in both directions. The column sizes are $400 \mathrm{X} 400 \mathrm{~mm}$ for all position and the slab thickness is $125 \mathrm{~mm}$. All beams are of same size with a width of $300 \mathrm{~mm}$ and depth including slab thickness of $500 \mathrm{~mm}$. The concrete strength is assumed to be $4000 \mathrm{psi}$ with yield strength $60000 \mathrm{psi}$ where Modulus of Elasticity (Young's Modulus) is 3600 ksi. Masonry infills were modeled as equivalent diagonal strut with width of $485 \mathrm{~mm}$ and thickness of $125 \mathrm{~mm}$. The masonry infill has compressive strength of $1 \mathrm{MPa}$. The model is assumed to be situated in Dhaka city so according to Bangladesh National Building Code (BNBC) seismic zone 2 is taken. Assuming standard occupancy structure and exposure category A, equivalent seismic loads are determined. The geometry and material characteristics together with the fact of that the infill is in direct contact 
with the fact reflect common practices of Bangladesh were infilled frames are not engineered to resist the seismic event properly. Most two common form of Shear wall, found in Bangladeshis modeled to evaluate the performance of shear wall and bare frame combination with respect to infill structures. Parallel and periphery shear wall were modeled using 10 inch wall with compressive strength of $4000 \mathrm{psi}$ and Modulus of Elasticity of $3600 \mathrm{ksi}$. Shear walls were modeled taking the half-length $2.5 \mathrm{~m}$ of each bay to resist the lateral loads only.

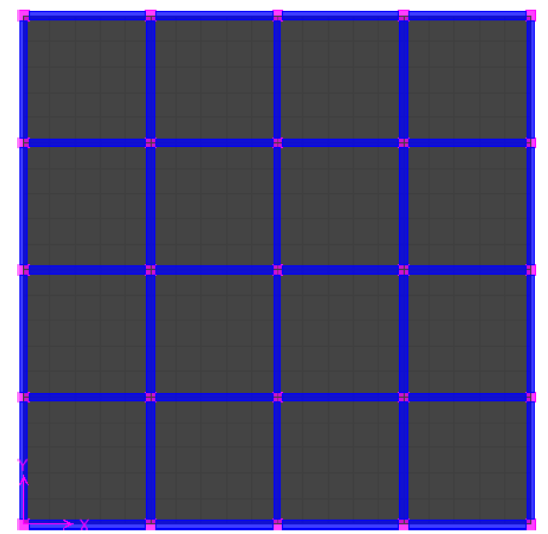

Figure 4. Typical Plan of the example building taken for this study

Moment hinges (M3) were assigned to both ends of beams and axial hinges (P-M-M) were assigned to the column ends. Geometric non linearity (P- $\Delta$ ) and large displacement is considered with full dead load and when local hinges fail redistribution of loads is allowed by unloading whole structure. The gravity loads used included self-weight of the members and loads of floor finish and live loads were applied to BNBC. All partition walls were assumed to be located directly on beams. The performance points marked by collapse and representing ultimate displacement capacity of the structure were evaluated at each step of the analysis according to guidelines of ATC-40 and FEMA 356.

\section{METHOD OF REPLACEMENT OF INFILL}

The approaches presented by Paulay and Pristlay (1992) and Angel et al.(1994), and later adopted by R. Shahrin \& T.R. Hossain ( 2011) lead to a simplification in the infilled frame analysis by replacing the masonry infill with an equivalent compressive masonry strut as shown in Figure 5-(a).

$\lambda 1 \mathrm{H}==\mathrm{H}\left[\left(\mathrm{E}_{\mathrm{m}} \mathrm{t} \sin 2 \theta\right) /\left(4 \mathrm{E}_{\mathrm{c}} \mathrm{I}_{\mathrm{col}} \mathrm{h}_{\mathrm{w}}\right)\right]^{1 / 4}$

where $t$ is the thickness of masonry wall. Main stone (1971) considers the relative infill-to-frame flexibility in the evaluation of the equivalent strut width of the panel as shown in Eq 2

$\mathrm{a}=0.175 \mathrm{D}(\lambda 1 \mathrm{H})-0.4$

If there are opening present, existing infill damage, and/or FRP overlay, however, the equivalent strut must be modified using

$\mathrm{A}_{\text {mod }}=\mathrm{a}(\mathrm{R} 1) \mathrm{i}(\mathrm{R} 2) \mathrm{i} \zeta 1$

Where,

$(\mathrm{R} 1) \mathrm{i}=$ reduction factor for in-plane evaluation due to presence of openings

$(\mathrm{R} 2) \mathrm{i}=$ reduction factor for in-plane evaluation due to existing infill damage

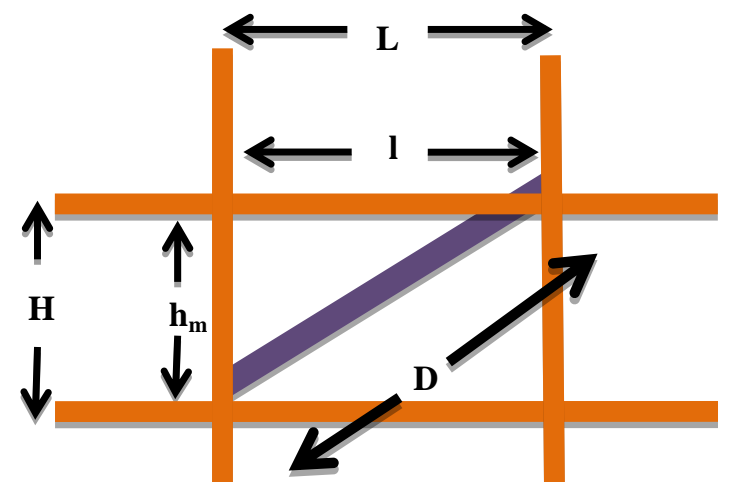

(a) Strut Geometry

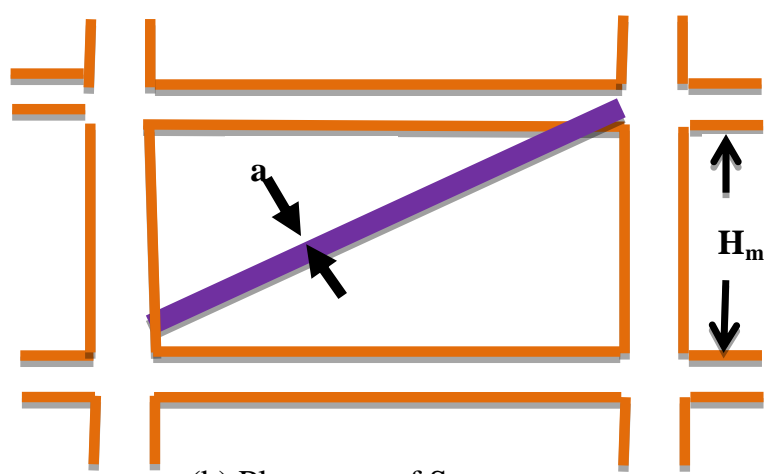

(b) Placement of Strut

Figure 5: (a) Strut Geometry (b) Placement of Strut 
Credit: R. Shahrin \& T.R. Hossain (2011)

$\zeta 1=$ strength increase factor due to presence of FRP overlay

Although the expression for equivalent strut width given by Eq 4 was derived to represent the elastic stiffness of an infill panel, this document extended its use to determine the ultimate capacity of in filled structures. The strut was assigned strength parameter consistent with the properties of the infill it represents. A nonlinear static procedure commonly referred to as pushover analysis, was used to determine the capacity of the infilled structure. The equivalent masonry strut is to be connected to the frame members as depicted in Figure 3. Where the bold double sided arrow represents the location of the strut in the structural model. The infill forces are assumed to be mainly resisted by the columns, and the struts are placed accordingly. The strut should be pin connected to the column at a distance $1_{\text {column }}$ from the face of the beam. This distance is defined in Eq 3 and Eq 5 and is calculated using the strut width, a, without any reduction factors.

$1_{\text {column }}=\mathrm{a} / \cos \theta_{\text {column }}$

$\tan \theta_{\text {column }}=\left\{\mathrm{h}_{\mathrm{m}}-\left(\mathrm{a} / \cos \theta_{\text {column }}\right)\right\} / 1$

The strut force is applied directly to the column at the edge of its equivalent strut width. Figure 5-(b) illustrates these concepts. Modulus of elasticity of the masonry units was chosen considering the ACI/ASCE/TMS masonry code as $1200 \mathrm{ksi}$.

\section{CASES FOR STUDY}

To meet the board objectives of the research, the research study is planned and oriented in such a way so that understanding becomes easy and meaningful. Depending upon the infill percentage so many probable cases may arise but few in this study $25 \%$ interval is taken in 4 X 4 span than a general trend may be established so a few cases are taken such as bare, $100 \%$ infill, $75 \%$ infill, $50 \%$ infill and $25 \%$ infill where each of the case represent a probable infill configuration. On the side, as shear wall cases are taken for study and comparison so two basic shear-walls are categorized into two groups: periphery shear-wall and parallel shear-wall. Finally to investigate the effects of soft storey will be identified as well so for this typical 6 story is oriented into 6 separate soft storey configuration Figure 6. As the objective is the elaborate study of pushover on these cases so each and every cases is assigned into a group so that the analysis is performed properly Table I. To observe the effects of shear-wall solely the shear wall with bare frame is simulated in this research Figure 7

Table I

Research Cases Categories

\begin{tabular}{|c|c|c|}
\hline Infill Percentage Cases & Soft Storey Cases & Shear-wall cases \\
\hline Bare Frame & GF Soft & Parallel SW \\
\hline $25 \%$ Infill & $1^{\text {st }}$ Floor Soft & Periphery SW \\
\hline $50 \%$ Infill & $2^{\text {nd }}$ Floor Soft & \\
\hline $75 \%$ Infill & $3^{\text {rd }}$ Floor Soft \\
\hline $100 \%$ Infill & $4^{\text {th }}$ Floor Soft \\
\hline
\end{tabular}

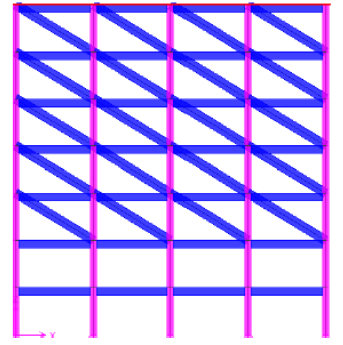

(a) Ground Floor Soft Storey

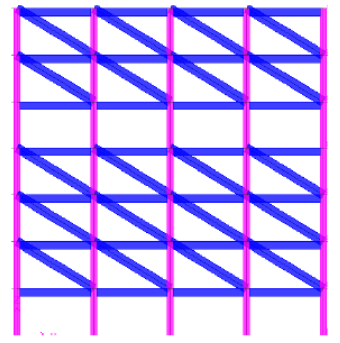

(d) $3^{\text {rd }}$ Floor Soft Storey

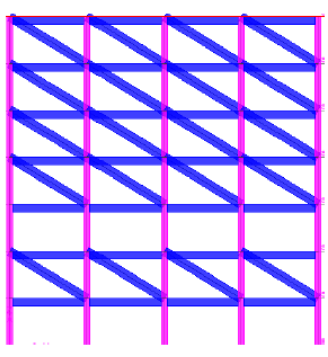

(b) $1^{\text {st }}$ Floor Soft Storey

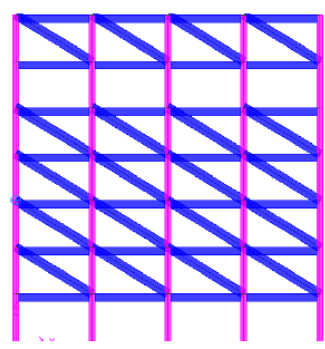

(e) $4^{\text {th }}$ Floor Soft Storey

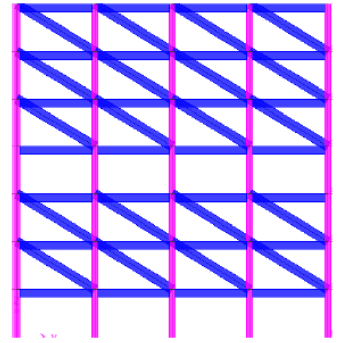

(c) $2^{\text {nd }}$ Floor Soft Storey

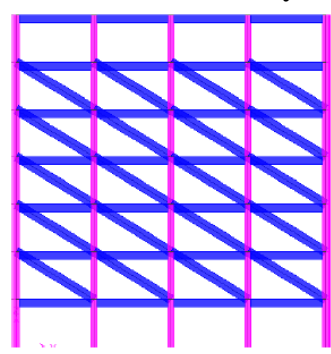

(f) $5^{\text {th }}$ Floor Soft Storey 
Figure 6: Elevation view for (a) GF Soft Storey (b) $1^{\text {st }}$ Floor Soft Storey (c) $2^{\text {nd }}$ Floor Soft Storey (d) $3^{\text {rd }}$ Floor Soft Storey (e) $4^{\text {th }}$ Floor Soft Storey and (f) $5^{\text {th }}$ Floor Soft Storey

The load deformation responses of the numerical model specimens were followed through to failure by means of the capacity curve. The curve was gained using pushover analysis, where the loading profile used was a triangular one com-menstruate to the dominate first mode distribution of the seismic loads.

For the pushover analysis, 3 load cases were considered:

$>$ PUSH1 - applying the gravity loads associated to load combinations which also contain seismic loadings.

$>$ PUSH2 - applying lateral loads in the X-X direction.

$>$ PUSH3 - applying lateral loads in the Y-Y direction
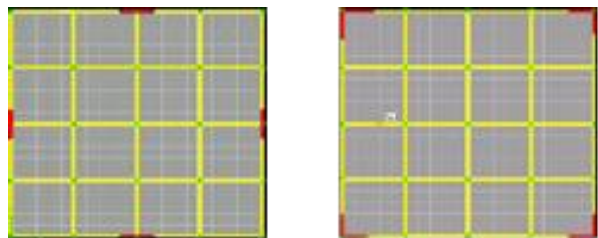

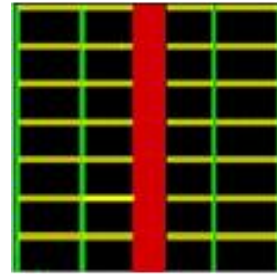

(a) Parallel Shear Wall

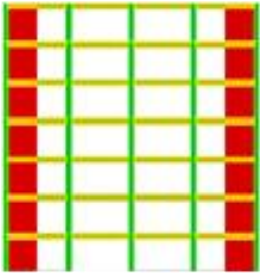

(b) Perip hery Shear Wall

Figure 7: (a) Plan and elevation view for bare frame with Parallel shear wall (b) Plan and elevation view for bare frame with Periphery shear wall

\section{RESULTS AND DISCUSSIONS}

Outcomes of analysis are organized to summarize how the structural responses differ with different infill percentage, construction of shear-wall in two opposite format and finally soft storey consisting building by pushover analysis. For that the performances of structures are evaluated with the help of base shear, performance point, deflection, storey drift and stages of number of hinges form for different cases which were evaluated under systematic review process.

\subsection{Comparison of Performance point and base shear:}

Seismic performance in terms of base shear, performance point and top displacement increase with shifting of soft storey upward in the structure. Performance point is much higher for shear wall consisting bare frames than any other configuration which propose bare frame could be a choice while using any types of shear wall Figure 8.

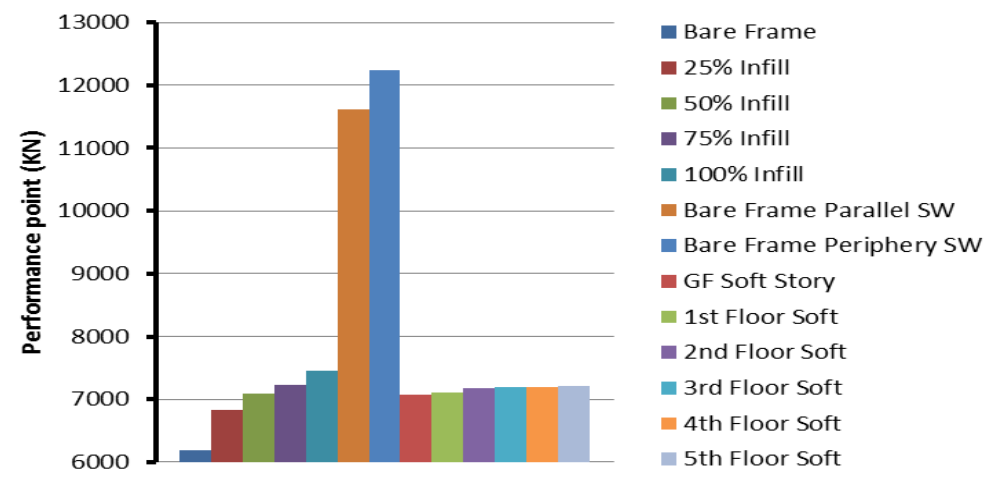

Figure 8: The comparison of performance point between different soft storey cases

General bare frame has very low resistance against lateral force even from any soft story case. As the soft story shifted above the performance also increased. Considering this point soft story could be setup in upper 
floor to improve the lateral load bearing capability relatively. Similar scenario is reflected in base shear too which is nothing but upper point of the performance point Figure 9.

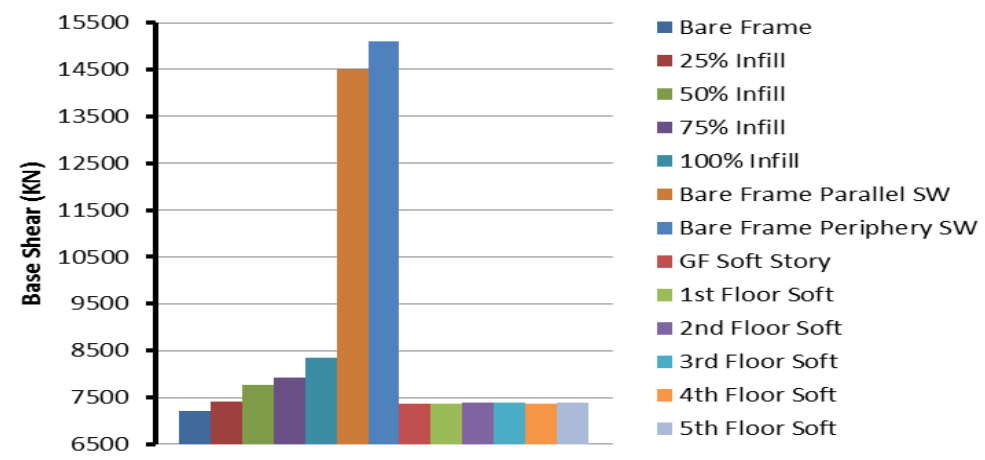

Figure 9: The comparison of base shear between different soft storey cases

The difference of performance point and base shear increases with shifting of soft storey upward and constructing the shear wall. It seems early formation of soft storey is not desired in the structures of highly seismic risk areas. On the other hand a special tendency is seen in performance and base a shear category that is in middle of the structure providing soft storey is not so bad because it is the point from which the shifting good effect goes downward again but minor in results.

\subsection{Number of hinges formation for different cases:}

As plastic hinges are applied in column, beam and strut to create nonlinear cases, they show structural condition through several stages Fig 10. Hinges goes to collapsible condition after passing a few intermediate stages i.e. immediate occupancy and life safety. In linear static only the final displacement found by providing a constant load where the pushover sequentially increases the load from low to the governing one. By producing plastic hinges it identify the change of state of each member in each pushover step.

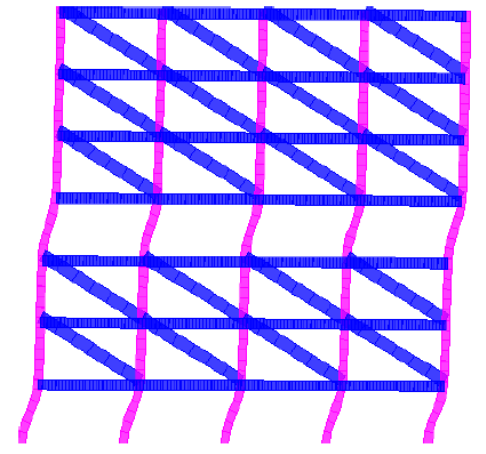

(a) Displacement under Linear Static Analysis

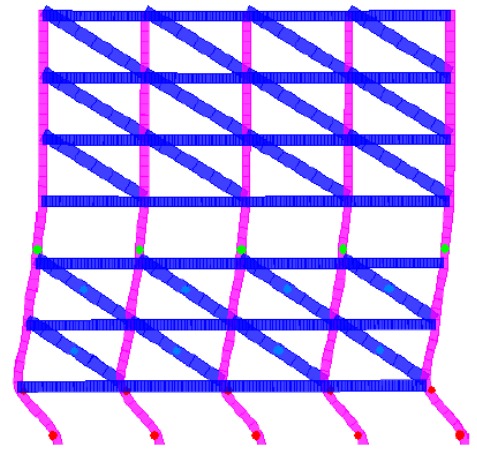

(b) Displacement under Pushover Analysis (Step 2)

Figure 10: Formation of plastic hinge in bare frame after performing nonlinear analysis

Formation of maximum number of hinges in early stage is not good for structure which eventually represents that early reaching to the collapsible condition Table II. Looking on the number of hinges formed one thing is cleare, higher infill ensures low number of hinge formation while shear wall significantly reduces the hinges formation than any other cases.

Table II

Number of hinges formed in Infill and Shear wall configuration

\begin{tabular}{|c|c|c|c|c|c|c|c|c|c|}
\hline & A-B & B-IO & IO-LS & LS-CP & CP-C & C-D & D-E & $>$ E & Total \\
\hline 25\% infill & 920 & 0 & 0 & 45 & 0 & 1 & 3 & 1 & 970 \\
\hline $\mathbf{5 0 \%}$ infill & 980 & 0 & 0 & 41 & 0 & 3 & 6 & 0 & 1030 \\
\hline 75\% infill & 1039 & 1 & 1 & 47 & 0 & 2 & 0 & 0 & 1090 \\
\hline $\mathbf{1 0 0 \%}$ infill & 1100 & 0 & 0 & 40 & 0 & 5 & 4 & 1 & 1150 \\
\hline Bare Frame & 760 & 30 & 45 & 67 & 0 & 4 & 4 & 0 & 910 \\
\hline $\begin{array}{c}\text { Bare Frame } \\
\text { Parallel SW }\end{array}$ & 618 & 58 & 150 & 80 & 0 & 4 & 0 & 0 & 910 \\
\hline $\begin{array}{c}\text { Bare Frame } \\
\text { Periphery SW }\end{array}$ & 600 & 66 & 131 & 109 & 0 & 4 & 0 & 0 & 910 \\
\hline
\end{tabular}


Whereas for the soft storey cases, it is seen that formation of plastic hinges become quite uniform by shifting of soft storey whereas here too, $3^{\text {rd }}$ Floor Soft storey is the peak point of the hogging characteristics Table III. So it is proven again neither early formation nor late formation is good but formation of soft storey in middle portion of the structure may be a better choice for construction decision makers and designers. Number of hinge formed for soft cases are higher than infill and shear wall cases.

Table III

Number of hinges formed in Soft Storey configuration

\begin{tabular}{|c|c|c|c|c|c|c|c|c|c|}
\hline & A-B & B-IO & IO-LS & LS-CP & CP-C & C-D & D-E & $>$ E & Total \\
\hline $\begin{array}{c}\text { Ground Floor } \\
\text { Soft }\end{array}$ & 1010 & 0 & 24 & 67 & 0 & 2 & 4 & 3 & 1110 \\
\hline $\mathbf{1}^{\text {st }}$ Floor Soft & 1025 & 10 & 25 & 45 & 0 & 2 & 3 & 0 & 1110 \\
\hline $\mathbf{2}^{\text {nd }}$ Floor Soft & 1035 & 25 & 0 & 45 & 0 & 3 & 2 & 0 & 1110 \\
\hline $\mathbf{3}^{\text {rd }}$ Floor Soft & 1060 & 0 & 0 & 40 & 0 & 5 & 2 & 3 & 1110 \\
\hline $\mathbf{4}^{\text {th }}$ Floor Soft & 1060 & 0 & 0 & 42 & 0 & 2 & 5 & 1 & 1110 \\
\hline $\mathbf{5}^{\text {th }}$ Floor Soft & 1060 & 0 & 0 & 45 & 0 & 1 & 4 & 0 & 1110 \\
\hline
\end{tabular}

\subsection{Comparison of Drift of soft storey cases:}

Storey drift is an important parameter to measure displacement changing characteristics which are used in performance based analysis such as pushover analysis, performed in our study. Storey drift is the total lateral displacement that occurs in a single story of a multistory building computed by Eq. 6. Gradual displacements changing ensure structural stability, uniform stiffness and less probability to evaluation of plastic hinges. Plastic hinges eventually goes to collapsible condition and cannot stand with load. To withstand against progressive loads formation of plastic hinge must be controlled by using special structural components. For the infill cases the scenario found worse as there is a sudden displacement change in the storey 1 under the specific seismic event make those cases less preferable than the shear wall cases Figure 11.

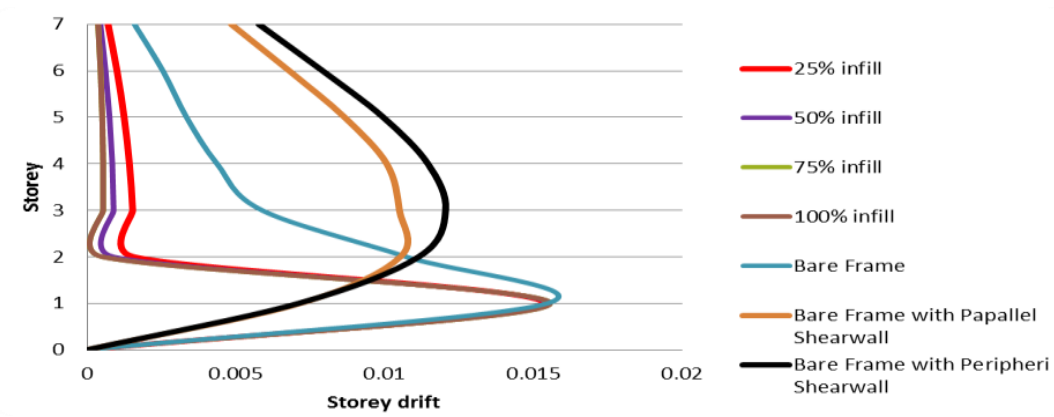

Figure 11: The comparison of story drift between different infill and shear wall cases

Whenever the drift ratios are considered the preference to the two types of shear wall get importance. Storey drift $($ of storey 2$)=($ displacement Storey 2 - displacement Storey 1$) /$ Storey height .....

In general soft storey causes higher drift in successive upper storey of soft storey. Trend is just similar to the others structural response. $3^{\text {rd }}$ storey soft floor show the last lower drift than any other. Other soft storey cases show worse condition by exhibiting much drift than $3^{\text {rd }}$ storey soft case Figure 12.

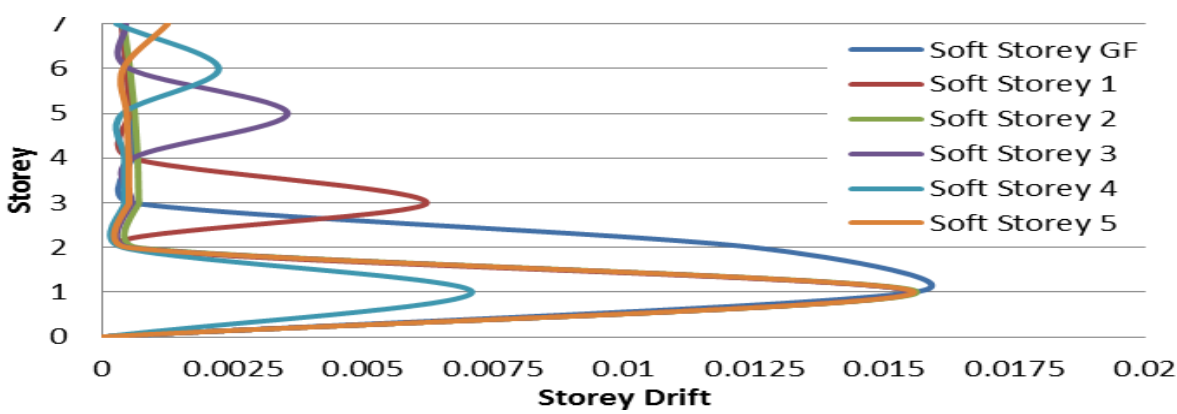

Figure 12: The comparison of story drift between different soft story cases 
Gradual displacements changing ensure structural stability, uniform stiffness and less probability to evaluation of plastic hinges. Plastic hinges eventually goes to collapsible condition and cannot stand with load. To withstand against progressive loads formation of plastic hinge must be controlled by using special structural components. For the all cases except $3^{\text {rd }}$ storey soft floor a summary scenario exhibit that structural performance goes to downward.

\section{CONCLUSION}

Summarizing the results lead to a decision that infill, shear wall and soft storey configuration significantly affects the performance of the structures of rigid joint. Under performance based analysis which is pushover, increasing infill increases the performance overall while shear wall has maximum resistance against any lateral loads. The comparison of performance of all soft storey cases under pushover analysis reveal that shipment of soft storey in each floor upward or downward has a significant effects.

\section{These are the conclusions drawn from the analyses:}

- The pushover analysis is a simple procedure to visualize the nonlinear characteristics of buildings.

- Structural performance are significantly affected by different infill configuration, soft storey and shear wall type.

- Increasing percentage of infill is good for structures for lateral loads.

- Shear wall is the ultimate lateral load bearing structures which tripled the resistance capacity of a frame.

- Considering periphery shear wall could be a better option for all directional lateral loads than parallel shear wall configuration.

- Formation of soft storey in upper floors are less worse than the formation in early floor.

- The improvement of performances increase with shifting of soft storey upward governs till half of the height of total building. After peak point it fall again to the worst so it could be a guideline to form soft storey in the half of the structure, is not bad at all.

It would be desirable to study more cases before reaching definite conclusions about the behavior of soft storey of reinforced concrete frame buildings of rigid joint.

\section{Acknowledgements}

The present authors, Yousuf Dinar, Md. Imam Hossain, Rajib Kumar Biswas and Md. Masud Rana thank Mr. Prottoy Hasan, Ex- Lecturer and Mr. Fateh Azam Khan, Assistant Professor, Department of Civil Engineering, University of Asia Pacific, Bangladesh for encouraging, sharing strategy and guiding during literature review and conducting the simulation work relating to Pushover Analysis.

\section{REFERENCES}

[1] Dinar, Y., Alam, M. N, and Paul, S. C "Performance Based Analysis of RC Building Consisting Shear Wall and Varying Infill Percentage", European Academic Research, Vol 1, Issue 9, December 2013, pp 2927-2947

[2] Dinar, Y., Karim, S. ,Barua, A and Uddin, A., “P-Delta Effect in Reinforced Concrete Structures of Rigid joint”, International Organization of Scientific Research: Journal of Mechanical and Civil Engineering, Vol 10, Issue 4,November-December2013, pp 42-49.

[3] Golghate, K, Baradiya, V and Sharma, A., "Pushover Analysis of 4 Storey's reinforced Concrete Building", International Journal of Latest Trends in Engineering and Technology, Vol 2, Issue 3, May 2013, pp 80-84.

[4] Ashraf Habibullah, S.E., and Stephen Pyle, S.E," Practical Three Dimensional Nonlinear Static Pushover Analysis" , Structure Magazine 1988

[5] BNBC (2006) Bangladesh National Building Code, Housing and Building Research Institute, Mirpur, Dhaka, Bangladesh.

[6] ATC (1996) Seismic Evaluation and Retrofit of Concrete Building (volume 1), Report (ATC-40), Applied Technology Council, California, USA.

[7] FEMA 356, 273.(2002) Pre-standard and Commentary for the Seismic Rehabilitation of Buildings, Federal Emergency Management Agency, Washington D.C., USA.

[8] Shahrin R. and ?Hossain T.R., "Seismic performance evaluation of residential buildings in Dhaka city by using pushover analysis", Proceedings of 4th Annual Paper Meet and 1st Civil Engineering Congress, Dhaka, Bangladesh, Vol 4, pp 547-556

[9] R.K.Biswas,Md.M Uddin,M.A. Chowdhury,and Md.Al Imra., "Comparative analysis of a 15 story flat plate building with and without shear wall building under wind and seismic loads". International Organization of Scientific Research (IOSR)-International Journal of Mechanical and Civil Engineering, Volume.9, Issue.2, (Sep-Oct, 2013), pp: 97-101.

[10] M.A. Chowdhury, R.K. Biswas, M.N. Nazmul Hoq, and S.M. Iskander, "Evaluation of the structural implication of incorporating Base Isolator as Earthquake Protection Device". International Organization of Scientific Research (IOSR)-International Journal of Mechanical and Civil Engineering, Volume.8, Issue.1, (Jul-Aug, 2013), pp:27-30. 